This is an electronic reprint of the original article. This reprint may differ from the original in pagination and typographic detail.

Author(s): Kemppainen, Birgitta; Laajalahti, Anne

Title: Viestintätoimijuuden edellytykset ja tukeminen asiantuntijatyössä

Year: $\quad 2016$

Version:

Please cite the original version:

Kemppainen, B., \& Laajalahti, A. (2016). Viestintätoimijuuden edellytykset ja tukeminen asiantuntijatyössä. Prologi : puheviestinnän vuosikirja 2016, 2016, 6-23.

All material supplied via JYX is protected by copyright and other intellectual property rights, and duplication or sale of all or part of any of the repository collections is not permitted, except that material may be duplicated by you for your research use or educational purposes in electronic or print form. You must obtain permission for any other use. Electronic or print copies may not be offered, whether for sale or otherwise to anyone who is not an authorised user. 


\title{
Artikkeli
}

Prologi - puheviestinnän

\section{Viestintätoimijuuden edellytykset ja tukeminen asiantuntijatyössä}

\author{
Birgitta Kemppainen \\ myyntiassistentti, FM \\ Balentor Oy \\ birgitta.kemppainen@balentor.fi
}

Anne Laajalahti

\section{Tiivistelmä}

Toimijuus on noussut viime aikoina keskeiseksi kiinnostuksen kohteeksi työssä oppimista ja ammatillisia identiteettejä koskevassa keskustelussa sekä laajemminkin aikuiskasvatustieteissä. Tässä artikkelissa ${ }^{1}$ keskitytään tarkastelemaan toimijuutta työyhteisöviestinnän näkökulmasta ja pohditaan, mitä viestintätoimijuus on tai voisi olla asiantuntijatyössä. Artikkelissa pyritään näin ollen valottamaan asiantuntijoiden viestinnällisen toimijuuden edellytyksiä ja tukemista. Artikkeli perustuu eräässä Väli-Suomen julkishallinnollisessa asiantuntijaorganisaatiossa tehtyyn haastattelututkimukseen. Tutkimusaihetta lähestyttiin laadullisen tutkimusotteen avulla asiantuntijoiden itsensä kokemana ja kuvaamana. Tutkimusaineisto kerättiin 12 teemahaastattelulla, ja se analysoitiin teoriasidonnaista sisällönanalyysia noudattaen. Tutkimustulokset tarjoavat näkökulmia asiantuntijoiden viestintätoimijuuden rakentumiseen ja rakentamiseen. Artikkelin keskeisintä antia on uuden viestintätoimijuuden käsitteen esille nostaminen ja esitteleminen. Käsitteellä viitataan ammatillista toimijuutta rajatumpaan prosessiin, jossa asiantuntijayksilöt, ryhmät tai kokonaiset työyhteisöt ilmaisevat ja työstävät työnsä viestinnällisiin aspekteihin liittyviä valintoja ja pyrkimyksiä, ottavat kantaa, osallistuvat ja vaikuttavat viestintään työssään sekä neuvottelevat ammatillisista identiteeteistään viestinnän osalta. Lisäksi artikkeli tarjoaa konkreettisia ehdotuksia, joiden avulla asiantuntijaorganisaatiot voivat yhdessä jokaisen jäsenensä voimin kehittää toimintaansa yksilöiden ja koko työyhteisön viestintätoimijuutta tukevaksi. Artikkelin lopussa pohditaan viestintätoimijuuden näkökulman merkitystä työyhteisöviestinnän ymmärtämisessä, kouluttamisessa ja tutkimisessa sekä viestintätoimijuuden tukemisen tärkeyttä yksilöiden ja työyhteisöjen kehittymisessä ja kehittämisessä. Tulokset tarjoavat hyödyllistä tietoa asiantuntijaorganisaatioille ja asiantuntijoille, jotka tahtovat panostaa aktiivisempien, vuorovaikutteisempien ja osallistavampien viestintätapojen hyödyntämiseen ja jalkauttamiseen. Artikkelissa tuodaan esille myös viestintätoimijuutta käsitteleviä jatkotutkimusaiheita työyhteisöviestinnän tutkijoille ja muille aiheesta kiinnostuneille.

ASIASANAT: asiantuntijatyö, toimijuus, työyhteisöviestintä, viestintätoimijuus, vuorovaikutusosaaminen 


\section{Johdanto}

Toimijuudesta (agency) on tullut viime aikoina keskeinen kiinnostuksen kohde työssä oppimista ja ammatillisia identiteettejä koskevassa keskustelussa, ja sitä on tutkittu ja käsitteellistetty yhä enenevässä määrin esimerkiksi aikuiskasvatuksessa, filosofiassa, sosiologiassa, sosiaalipsykologiassa, psykologiassa, antropologiassa ja naistutkimuksessa. Toimijuudella tarkoitetaan eri tieteenaloilla ja eri yhteyksissä eri asioita, mutta usein määritelmissä korostuvat yksilön tai yhteisön aktiivisuus, aloitteellisuus, intentionaalisuus, osallisuus, hallinnan kokemus, vapaaehtoisuus sekä valinnan ja vaikuttamisen mahdollisuudet. (Ks. esim. Eteläpelto ym. 2013; 2014; Vähäsantanen 2013.)

Tarve keskustella ammatillisesta toimijuudesta (professional agency) työssä on lisääntynyt monesta syystä. Työelämän vaatimukset ja jatkuvat muutokset edellyttävät erilaisen ja eritasoisen ammatillisen toimijuuden vahvistamista työssä (Eteläpelto ym. 2014, 202; Kerosuo 2014, 178). Nykyinen työelämä edellyttää työntekijöiltä osallistuvaa, kehittämisorientoitunutta ja innovatiivista toimijuutta (Haapasaari, Engeström \& Kerosuo 2016, 232). Työelämä asettaa toimijuudelle kuitenkin ristiriitaisia vaatimuksia. Samaan aikaan kun työntekijöiden edellytetään olevan aloitteellisia, kriittisiä ajattelijoita, luovia, vastuullisia, yrittäjämäisiä ja pystyvän jatkuvasti uusiutumaan ammatillisesti sekä luomaan työssään uutta, monet työntekijät kokevat ulkoisen kontrollin ja valvonnan kiristyneen työssään. (Vähäsantanen 2013, 108.)

Organisaatioiden toiminnasta on tullut yhä tietointensiivisempää, ja muun muassa tieto- ja viestintätekniikan kehitys, työn uudenlainen organisoituminen, uudet sosiaaliset ja vuorovaikutteiset viestintäareenat sekä niihin liittyvän jakamista korostavan viestintäkulttuurin leviäminen ovat vaikuttaneet myös työyhteisöjen viestintään (Alasoini, Järvensivu \& Mäkitalo 2012, 1-5; Li 2010, 6). Tietointensiivisissä asiantuntijaorganisaatioissa työskentely vaatii muun muassa itseohjautuvuutta, analyyttisyyttä, luovuutta, ongelmanratkaisukykyä, tieto- ja viestintäteknistä osaamista sekä vuorovaikutusosaamista (Huotari, Hurme \& Valkonen 2005, 25; Pyöriä 2006, 55-90). Kuvatut kehityssuunnat viestinnässä edellyttävät henkilöstöltä myös vahvaa sitoutumista, vastuullista autonomiaa sekä parempia vaikutusmahdollisuuksia (Julkunen 2011, 43).

Tulevaisuuden työn on ennustettu korostavan entisestään vuorovaikutusosaamista ja vaativan vapauden vastapainona yhä vahvemmin itsensä johtamista ja vastuunottamista työnteosta, omista valinnoista, viihtymisestä ja hyvinvoinnista (Tulevaisuusselonteko 2030). Vaikka tämänkaltaiset muutokset näyttäisivät edellyttävän nimenomaan asiantuntijoiden aktiivista osallistumista ja vaikuttamista työyhteisönsä viestintään, asiantuntijatyötä ei ole aiemmin lähestytty viestinnällisen toimijuuden näkökulmasta. Tässä artikkelissa tarkastellaan toimijuutta työyhteisöviestinnän näkökulmasta ja valotetaan viestintätoimijuuden edellytyksiä ja tukemista asiantuntijatyössä. Viestintätoimijuudella tarkoitetaan ammatillista toimijuutta rajatumpaa prosessia, jossa asiantuntijayksilöt, ryhmät tai kokonaiset työyhteisöt ilmaisevat ja työstävät työnsä viestinnällisiin aspekteihin liittyviä valintoja ja pyrkimyksiä, ottavat kantaa, osallistuvat ja vaikuttavat viestintään työssään sekä neuvottelevat ammatillisista identiteeteistään viestinnän osalta.

Artikkelin teoriaosuudessa tarkastellaan toimijuuden käsitettä ja tutkimusta keskittyen ammatilliseen toimijuuteen työssä. Lisäksi käsitellään asiantuntijaorganisaatioita toimijuuden areenana ja määritellään sisäisen viestinnän 
sekä työyhteisöviestinnän käsitteet. Tutkimuskysymysten ja -menetelmien jälkeen käydään läpi keskeisimmät tutkimustulokset, jonka jälkeen pohditaan tulosten merkitystä työyhteisöviestinnän kehittämisessä ja tuodaan esille keskeisimmät jatkotutkimushaasteet.

\section{Toimijuuden käsite ja tutkimus}

Vaikka toimijuuden käsitettä on alettu käyttää monilla tutkimusalueilla aktiivisesti ja eksplisiittisesti vasta viime aikoina, toimijuuden idea ei sinänsä ole uusi. Toimijuuden juuret palautuvat valistuksen aikaan ja ajatukseen kasvatuksen roolista kahlitsevista traditioista vapautumisessa ja oman elämän hallinnassa (Silvennoinen 2014, 162). Toimijuuden idean voidaan nähdä kytkeytyvän myös esimerkiksi kriittisen tietoisuuden ja emansipatorisen eli vapauttavan oppimisen kautta tapahtuvaan valtautumiseen ja voimaantumiseen (empowerment) (Mezirov 1991; ks. lisäksi Eteläpelto ym. 2013, 46) tai refleksiivisyyteen, jolloin toimijuutta voidaan tarkastella käyttäytymisen prosessina, joka koostuu kolmesta tietoisesta vaiheesta: 1) toiminnan suunnittelusta, 2) toiminnan valinnasta sekä 3) toiminnan toteuttamisesta (Archer 2010, 23).

Toimijuutta on tarkasteltu toisinaan yleisesti teoreettisella ja tieteenfilosofisella tasolla (ks. esim. Eteläpelto ym. 2013; 2014). Toisinaan kiinnostuksen kohteena on ollut rajatummin toimijuus jossain tietyssä kontekstissa, jonkin tietyn aspektin suhteen tai jonkin tietyn ihmisryhmän keskuudessa. Tällöin tarkastelu on voinut keskittyä esimerkiksi muutostoimijuuteen (transformative agency) (Haapasaari, Engeström \& Kerosuo 2016), strategiseen toimijuuteen (Laulainen 2010), suhteisiin perustuvaan toimijuuteen (relational agency) (Edwards 2005), retoriseen toimijuuteen (Campbell 2005), lasten (Lehtinen 2000), nuorten aikuis- ten (Evans 2007) tai ikääntyvien ihmisten toimijuuteen (Jyrkämä 2008) tai vaikkapa toimijuuteen yksinasuvien muistisairaiden naisten arjessa (Virkola 2014). Lähestymistapana on voinut olla myös esimerkiksi toimijuuden tukeminen ohjaustyössä (Vanhalakka-Ruoho 2014) tai työelämäinterventioiden avulla (Vähäsantanen ym. 2014).

Hitlinin ja Elderin (2007) mukaan toimijuutta voidaan jäsentää ja linkittää erilaisiin teoria- ja tutkimustraditioihin neljästä näkökulmasta. Nämä ovat 1) yleisessä mielessä toiminnan intentionaalisuutta, itseohjautuvuutta ja aloitteellisuutta sekä ihmisen valinnanvapautta tarkasteleva eksistentiaalinen toimijuus (existential agency), 2) ainutkertaisen nykyhetken valintoihin ja rutiinien rikkoutumiseen kietoutuva pragmaattinen toimijuus (pragmatic agency), 3) erilaisissa rooleissa ja toimintaympäristöissä identiteetin rakentumiseen liittyvä identiteettitoimijuus (identity agency) ja 4) ihmisen koko elämänkulkuun liittyvä toimijuus (agency in the life course).

Eteläpellon ym. $(2013 ; 2014)$ mukaan toimijuuden tutkimuksesta on sen sijaan erotettavissa seuraavat neljä tutkimustraditiota: 1) Sosiologisessa keskustelussa on korostettu rakenteita, diskursseja ja valtaa sekä niiden rajoittavaa ja mahdollistavaa vaikutusta yksilöiden toimijuuteen. 2) Jälkistrukturalistisessa naistutkimukses$s a$ on pohdittu muun muassa sitä, miten kieli ja puhetavat luovat toimijuuteen vaikuttavia valtarakenteita. 3) Sosiokulttuurinen lähestymistapa on painottanut sosiokulttuurisen kontekstin merkitystä ihmisen toiminnan välittäjänä. 4) Elämänkulkututkimuksessa toimijuuden on nähty ilmenevän tekoina ja valintoina, jotka rakentavat yksilöiden elämänkulkua ja liittyvät myös identiteettityöhön. 
Keskeisimmät erot lähestymistavoissa kulminoituvat ensinnäkin kysymykseen, miten toimijuuden ontologia hahmotetaan. Toimijuus näyttäytyy suppeimmillaan ymmärrettynä yksittäisinä rationaalisina ja intentionaalisina tekoina, kun taas laajimmillaan sen nähdään sisältävän niin ihmisen yksilökehityksellisen elämänkulun kuin sitä ympäröivät yhteiskunnalliset rakenteet (ks. koonteja esim. Eteläpelto ym. 2013; 2014).

Toinen keskeinen ero palautuu sosiologian ikuisuuskysymykseen toimijan ja rakenteiden suhteesta ja siitä, voiko toimijan ja rakenteiden tarkastelun ylipäänsä erottaa. Yksilöllisen ja sosiaalisen välinen suhde voidaan hahmottaa analyyttisesti erilliseksi ja vastavuoroiseksi tai myös toisistaan erottamattomaksi (Laulainen 2010, 30). Mikäli toimijuuden yksilölliset ja sosiaaliset aspektit hahmotetaan erillisiksi, on usein päädytty jonkinasteiseen toimijan/ toiminnan ja rakenteiden väliseen vastakkainasetteluun ja niiden tärkeyden arvottamiseen (Laulainen 2010, 30; Settersten \& Gannon 2005, 35). Settersten ja Gannon (2005, 35-37) erottavat kolme tapaa hahmottaa toimijuuden ja rakenteiden suhdetta: 1) sosiaalisten ja yhteiskunnallisten rakenteiden merkitystä painottava lähestymistapa (structure without agency), 2) yksilön kykyjä, tavoitteita, päätöksiä ja toimintaa korostava lähestymistapa (agency without structure) sekä 3) toimijuutta sosiaalisissa ja yhteiskunnallisissa rakenteissa tarkasteleva lähestymistapa (agency within structure). Karkeistaen toisissa lähestymistavoissa painottuu siis tahtova ja toimiva yksilö henkilökohtaisine pyrkimyksineen, valintoineen ja resursseineen, kun taas toisissa korostetaan esimerkiksi sosiaalisten ja yhteiskunnallisten rakenteiden, olosuhteiden, instituutioiden sekä vallan toimijuudelle asettamia mahdollisuuksia ja rajoituksia (ks. koonteja esim. Hitlin \& Elder 2007; Settersten \& Gannon 2005).
Kolmas ero lähestymistapojen välillä on, kenen tai minkä toimijuutta tarkastellaan. Toimijuus voi olla yksilöllistä tai yhteisöllistä ja kollektiivista, ja sitä voidaan tarkastella joko yksilön, ryhmän, yhteisön tai jonkin muun laajemman sosiaalisen kokonaisuuden tasolla. Toimijuutta voi siis olla esimerkiksi työntekijöillä, ryhmillä tai vaikkapa kokonaisilla työyhteisöillä (ks. esim. Eteläpelto ym. 2013; 2014).

\section{Toimijuus työelämässä}

Tässä artikkelissa keskitytään toimijuuden tarkasteluun nimenomaan asiantuntijatyön kontekstissa. Toimijuus yhdistyy työelämässä esimerkiksi rakenteelliseen vallankäyttöön, sosiaalisiin suhteisiin, puhetapoihin ja ihmisten väliseen epäviralliseen valtaan. Ammatillisen toimijuuden on nähty liittyvän niin työntekijöiden vaikutusmahdollisuuksiin ja vastarintaan kuin luovuuteen, motivaatioon ja työkäytäntöjen kehittämiseen. (Eteläpelto ym. 2014, 202.)

Eri tutkimustraditiot ovat painottaneet toimijuuden tarkastelussa eri näkökulmia, mutta yhteistä niille näyttäisi olevan ajatus toimijuudesta jonakin arvokkaana ja edistämisen arvoisena (Silvennoinen 2014, 162). Ammatillista toimijuutta tarvitaan työn ja työolojen kehittämisessä, työssä oppimisessa ja ammatillisista identiteeteistä neuvotellessa. Identiteetti voidaan ymmärtää yksilön elämänhistoriaan perustuvaksi käsitykseksi ja kokemukseksi itsestään, joka koostuu muun muassa henkilökohtaisista piirteistä, kiinnostuksen kohteista, kyvyistä sekä arvomaailmasta. Ammatillisen identiteetin voidaan taas nähdä rakentuvan prosessissa, jossa yksilö määrittelee nimenomaan työhön liittyvää minuuttaan eli esimerkiksi omaa rooliaan ja asemaansa työyhteisössä sekä sitä, kuinka vahvasti hän samastuu organisaatioonsa. (Kallio 2014, 4-5.) Toimijuuden kautta työntekijät voivat vaikuttaa, mikä lisää turvallisuutta, 
hyvinvointia ja mahdollisuutta kehittää omaa työtä ja osaamista. Tämä parantaa taasen työn tuottavuutta ja laatua. (Eteläpelto ym. 2014, 212.) Lisäksi toimijuus edistää organisaatioon sitoutumista, työtyytyväisyyttä ja työssä jaksamista (Vähäsantanen 2013, 111). Voidaankin koota, että toimijuus lisää sekä työntekijöiden vaikutusmahdollisuuksia ja hyvinvointia että organisaatioiden uudistumista ja innovatiivisuutta.

Laulainen $(2010,34)$ huomauttaa, että lähestyttäessä toimijuutta lähtökohtaisesti tarpeellisena ja tavoiteltavana, sen sisältö ja kontekstuaalisuus jää usein huomioimatta. Onkin muistettava, että vaikka toimijuuteen liitetään usein positiivisia konnotaatioita esimerkiksi luovuudesta, motivaatiosta, hyvinvoinnista ja jopa onnellisuudesta, myös kriittinen asennoituminen, muutosten vastustaminen ja työpaikan vaihtaminen osoittavat toimijuutta (ks. koontia Eteläpelto ym. 2013). Toimijuudesta puhuttaessa korostetaan usein myös aktiivisuutta ja näkyvien tulosten saavuttamista, vaikka myös tekemättä jättäminen, vetäytyminen ja odottamaan jääminen sekä vastarinta ja vastoin odotuksia toimiminen ovat nekin toimijuutta (Vanhalakka-Ruoho 2014, 198).
Ammatillinen toimijuus voidaan määritellä prosessiksi, joka ilmenee, kun työntekijät tai työyhteisöt vaikuttavat, tekevät valintoja ja ottavat kantaa työhönsä tai ammatillisiin identiteetteihinsä (Eteläpelto ym. 2014, 211). Näin ollen ammatillinen toimijuus eroaa ammatillisesta toimijasta ja esimerkiksi toimijan ammatillisesta identiteetistä ja osaamisesta. Työhistoria ja -kokemus, osaaminen ja asiantuntijuus ovat kuitenkin ammatillisen toimijuuden resursseja. Lisäksi toimijuus kytkeytyy työyhteisön resursseihin ja työpaikan sosiokulttuurisiin olosuhteisiin, jotka vaikuttavat siihen, millainen toimija yksilö tai yhteisö voi kulloinkin olla. Tällaista lähestymistapaa toimijuuteen voidaan kutsua subjektikeskeiseksi sosiokulttuuriseksi lähestymistavaksi, sillä se ottaa huomioon sekä työntekijöiden yksilöllisen taustan että ympäröivät sosiaaliset olosuhteet. (Eteläpelto ym. 2013; 2014; Vähäsantanen 2013.) Ammatillista toimijuutta ja siihen liittyviä tekijöitä on havainnollistettu kuviossa 1 .

Ammatillinen toimijuus voidaan määritellä myös yksilöiden, ryhmien tai työyhteisöjen kyvyksi vaikuttaa omaan työhönsä ja sen toteuttamiseen (Kerosuo 2014, 178). Tässä artikkelissa nojataan edellä esitettyyn subjektikeskeiseen

\begin{tabular}{|c|c|c|}
\hline TYÖPAIKAN & & AMMATILLISET \\
\hline SOSIOKULTTUURISET & AMMATILLINEN TOIMIJUUS & TOIMIJAT \\
\hline OLUSU HIELI & Ilmenee, kun työntekiiät ja/tai & \\
\hline Materiaaliset ehdot & $\begin{array}{l}\text { Ilmenee, kun tyontek1jat ja/ta1 } \\
\text { työyhteisöt vaikuttavat, }\end{array}$ & identiteetti \\
\hline Fyysiset artefaktit & tekevät valintoja ja ottavat kantaa & Ammatillinen \\
\hline Valtasuhteet & niin, että he vaikuttavat & $\begin{array}{l}\text { osaaminen ja } \\
\text { kompetenssit }\end{array}$ \\
\hline Työkulttuurit & $\begin{array}{c}\text { työhönsä ja/tai ammatillisiin } \\
\text { identiteetteihinsä. }\end{array}$ & Työhistoria ja \\
\hline Vallitsevat puhetavat & & -kokemus \\
\hline
\end{tabular}

KUVIO 1 Ammatillinen toimijuus ja siihen liittyvät tekijät (Eteläpelto ym. 2014, 211) 
sosiokulttuuriseen lähestymistapaan (ks. Eteläpelto ym. 2013; 2014) ja nähdään, että tuo "kyky" rakentuu yksilöllisten ja yhteisöllisten tekijöiden vuorovaikutuksessa. Vähäsantasen $(2013,112)$ sanoin toimijuuden nähdään siis olevan yksilöllisesti ja sosiaalisesti resursoitua. Artikkelissa hahmotetaan, että "kyky vaikuttaa" on "mahdollisuutta vaikuttaa", eikä toimijuudella tarkoiteta kykyä esimerkiksi osaamisen tai taidon merkityksessä, niin kuin on toisinaan ehdotettu (ks. esim. Campbell 2005, 3).

Artikkelissa ajatellaan, että viestintätoimijuus on ammatillista toimijuutta rajatumpi prosessi, joka tulee näkyväksi, kun tarkastellaan, millä tavoin asiantuntijayksilöt, ryhmät tai kokonaiset työyhteisöt ilmaisevat ja työstävät työnsä viestinnällisiin aspekteihin liittyviä valintoja ja pyrkimyksiä, ottavat kantaa, osallistuvat ja vaikuttavat viestintään työssään sekä neuvottelevat ammatillisista identiteeteistään viestinnän osalta. Niin ammatillista toimijuutta kuin viestintätoimijuutta toteutetaan ja ilmennetään viestinnässä ja vuorovaikutuksessa, mutta tässä artikkelissa hahmotetaan, että viestintätoimijuus on ammatillisen toimijuuden ulottuvuus, joka myös kohdistuu nimenomaan viestintään.

Esitetty viestintätoimijuuden käsite vahvistaa ja syventää toimijuuden ja työelämän viestintätutkimuksia kahdella tapaa. Ensinnäkin se rajaa ammatillisen toimijuuden tarkastelun työyhteisöviestinnän näkökulmaan: artikkelissa käsitteellistetään viestintätoimijuutta suhteessa laajempaan ammatillisen toimijuuden käsitteeseen ja sovelletaan nimenomaan asiantuntijaorganisaatioiden sisäiseen työyhteisöviestintään. Lisäksi viestintätoimijuuden käsite suuntaa työyhteisöviestinnän tarkastelua esimerkiksi vuorovaikutusosaamisen tutkimusta laajemmalle.

Puheviestinnässä ja lähitieteenaloilla on tutkittu jo melko runsaasti vuorovaikutusosaamista työelämässä ja laajemminkin yhteiskunnassa (ks. koonteja esim. Greene \& Burleson 2003; Laajalahti 2014; Spitzberg \& Cupach 2011). Vuorovaikutusosaamisella tarkoitetaan tietoa ja ymmärrystä, taitoja, motivaatiota sekä asenteita, joita voidaan pitää vuorovaikutuksessa tehokkaina ja tarkoituksenmukaisina (ks. esim. Spitzberg \& Cupach 2011). Vuorovaikutusosaamiseen on liitetty myös kyky tehdä tulkintoja ja tietoisia päätöksiä, joiden myötä yksilö joko mukautuu vuorovaikutustilanteeseen ja päämääriinsä sopivalla tavalla tai tarpeelliseksi kokiessaan pyrkii muokkaamaan vallitsevia olosuhteita (Barge 2014, 138, 144). Vaikka myös vuorovaikutusosaamisen katsotaan useimmiten olevan sekä yksilöllisten että kontekstuaalisten tekijöiden summa, on käsitteiden tausta ja ontologia erilainen ja viestintätoimijuus vuorovaikutusosaamista laajempi käsite. Artikkelissa nähdään, että viestintätoimijuus on prosessi ja vuorovaikutusosaaminen yksi viestintätoimijuuden resurssi, sillä vuorovaikutusosaaminen vaikuttaa osaltaan siihen, miten viestintätoimijuus voi toteutua ja millainen toimija esimerkiksi yksilö tai työyhteisö voi olla. Viestintätoimijuuteen vaikuttavat kuitenkin - vuorovaikutusosaamisen ohella - myös monet muut yksilölliset ja sosiokulttuuriset tekijät, kuten identiteetti, ammatilliset positiot, rakenteellinen vallankäyttö ja ihmisten väliset valtasuhteet.

\section{Asiantuntijatyö toimijuuden areenana}

Asiantuntijatyö luo viestintätoimijuudelle kiintoisan areenan. Vaikka asiantuntijatyöhön sisältyy myös yksilöllisen työn vaiheita, sitä tehdään tyypillisesti yhdessä toisten ihmisten kanssa: erilaisissa ryhmissä, verkostoissa ja yhteistyösuhteissa. Asiantuntijatyö ei perustu yksilösuorituksiin vaan ennen kaikkea vuorovaikutuksessa syntyviin ratkaisuihin ja 
ymmärrykseen (Edwards 2010, 22). Viestintä, vuorovaikutus ja yhteistyö sekä vaikuttaminen, aktiivisuus ja jatkuva neuvottelu ammatillisesta identiteetistä ovatkin asiantuntijatyön keskeisiä elementtejä. Omaa asiantuntemusta ja työn tuloksia kehitetään ja tehdään näkyväksi myös oman työyhteisön kesken: työyhteisö on yksi tärkeä tila, jossa asiantuntijatyö toteutuu. Tämän vuoksi myös työyhteisöviestinnän kehittämiseen liittyvällä viestintätoimijuudella on asiantuntijatyössä tärkeä rooli.

Sisäisen viestinnän (internal communication) on perinteisesti nähty koostuvan organisaation sisällä tapahtuvista viestintätoiminnoista, kuten tärkeimpien prosessien ja muutosten tukemisesta, organisaation jäsenten sitouttamisesta sekä tiedon tuottamisesta heidän käyttöönsä, kun taas ulkoisen viestinnän (external communication) on nähty sisältävän organisaation viestinnän sen ulkopuolisten sidosryhmien ja toimintaympäristön kanssa (Mazzei 2010; Vos \& Schoemaker 2011). Jaottelua voidaan kuitenkin pitää vanhanaikaisena, sillä esimerkiksi uudet viestintätekniikat ja sosiaalinen media ovat hämärtäneet sisäisen ja ulkoisen viestinnän rajoja. Rajojen hämärtymisestä kertoo myös sisäisen viestinnän levittäytyminen kaikille organisaation tasoille ja yhä useammalle jäsenelle, kanavalle ja areenalle. (Juholin 2013, 24-25; Men 2014, 265-266.) Mazzein (2010, 230) mukaan sisäinen viestintä voidaankin määritellä nykyisin perinteisten organisaatiorajojen sijaan abstraktien asioiden, kuten tiedon, viestintäkäytäntöjen ja vuorovaikutuksen, kautta.

Organisaation sisäisestä viestinnästä puhuttaessa voidaan käyttää työyhteisöviestinnän käsitettä, jolla tarkoitetaan kaikkea työyhteisössä tapahtuvaa viestintää ja vuorovaikutusta, mitä eri jäsenten ja ryhmien välillä esiintyy niin muodollisilla kuin epämuodollisilla foorumeilla (Juholin 2013, 85). Tässä artikkelissa sisäinen viestintä ymmärretään synonyymisesti työyhteisöviestinnän kanssa ja käsitteitä käytetään toiston välttämiseksi rinnakkain. Niillä tarkoitetaan siis kaikkea sitä ihmisten välistä muodollista ja epämuodollista viestintää ja vuorovaikutusta, jota tarvitaan työyhteisöissä työn tekemisessä, vuorovaikutussuhteiden rakentamisessa ja ylläpitämisessä sekä yhteisten tavoitteiden neuvottelemisessa ja saavuttamisessa. Työyhteisöviestinnän avulla luodaan uutta tietoa, ylläpidetään ja kehitetään työyhteisöä sekä opitaan uusia asioita ja luodaan siten edellytyksiä työnteolle (Juholin 2013, 85-86).

\section{Tavoite ja menetelmä}

Artikkelissa tarkastellaan toimijuutta työyhteisöviestinnän näkökulmasta ja pohditaan, mitä viestintätoimijuus on tai voisi olla asiantuntijatyössä. Viestintätoimijuus ymmärretään prosessina, jossa asiantuntijayksilöt, ryhmät tai kokonaiset työyhteisöt ilmaisevat ja työstävät työnsä viestinnällisiin aspekteihin liittyviä valintoja ja pyrkimyksiä, ottavat kantaa, osallistuvat ja vaikuttavat viestintään työssään sekä neuvottelevat ammatillisista identiteeteistään viestinnän osalta. Tutkimus perustuu eräässä Väli-Suomen julkishallinnollisessa asiantuntijaorganisaatiossa koettuun tarpeeseen kehittää sisäistä viestintää asiantuntijoiden osallistumismahdollisuuksia ja kollektiivista tiedonhallintaa tukevaksi. Tavoitteena on ymmärtää asiantuntijoiden viestintätoimijuuden edellytyksiä ja tukemista. Tutkimuskysymys on seuraava: Mitkä yksilölliset ja sosiokulttuuriset tekijät tukevat viestintätoimijuuden rakentumista asiantuntijatyössä?

Tutkimusaihetta lähestyttiin laadullisen tutkimusotteen avulla asiantuntijoiden itsensä kokemana ja kuvaamana. Yleistettävyyden sijaan tavoiteltiin mahdollisuutta ymmärtää viestintätoimijuutta ja analysoida aineistoa mahdolli- 
simman syvällisesti. Tutkimusaineisto kerättiin 12 teemahaastattelulla, sillä haastattelemalla on mahdollista tuoda vapaamuotoisesti esiin haastateltavien omia näkemyksiä, saada tietoa heidän ajatuksistaan ja syistä heidän toimintansa taustalla sekä varmistaa tärkeimpien aiheiden käsittely jokaisen haastateltavan kohdalla (Eskola \& Suoranta 1996, 65-67; Hirsjärvi \& Hurme 2001, 48; Tuomi \& Sarajärvi 2004, 73-75). Kohderyhmäksi rajattiin asiantuntijoina toimivat työntekijät, koska heidän kokemuksistaan ja viestintätoimijuuden vahvistamiseen liittyvistä tarpeistaan haluttiin tietoa johdon päätöksenteon tueksi. Näin ollen johdon edustajia lukuun ottamatta koko kohdeorganisaation jäsenistö nähtiin tutkimukseen sopivina osallistujina eli henkilöstöä edustavina asiantuntijoina, ja heille kaikille tarjottiin mahdollisuus osallistua teemahaastatteluihin lähettämällä heille sähköpostitse kutsu haastatteluun sisäisen viestinnän kehittämiseksi.

Kaikilla haastateltavilla oli kokemusta viestinnän roolista asiantuntijatyössä omassa työyhteisössään. Haastateltavina oli kaksi miestä ja kymmenen naista, joiden työkokemuksen kesto vaihteli puolen ja 22 vuoden välillä. Haastattelut toteutettiin touko- ja kesäkuussa 2015, ja ne kestivät keskimäärin yhden tunnin. Ennen varsinaisia haastatteluja haastattelurunko testattiin kolmella pilottihaastattelulla, minkä jälkeen kysymyksiä muotoiltiin hieman saadun palautteen perusteella. Haastattelurunko toimi ohjaavana pohjana, mutta kysymykset ja niiden järjestys vaihtelivat haastateltavien ja heidän vastaustensa mukaan. Jokaisessa haastattelussa huolehdittiin kuitenkin, että kaikki haastatteluteemat tulivat käsitellyiksi. Pääteemoja olivat 1) avoimuus, 2) tiedon jakaminen ja vuorovaikutus sekä 3) asiantuntijan rooli. Viestintätoimijuutta - eli tämän artikkelin aihetta - käsittelevät kysymykset kartoittivat erityisesti viestinnän roolia omassa asiantuntijatyössä, viestinnällisen vastuun kokemista sekä koettuja viestintätoimijuutta tukevia ja rajoittavia tekijöitä. Haastattelukysymyksiä olivat muun muassa seuraavat: Mikä motivoi jakamaan omaa tietopääomaa ja osaamista muille työyhteisön jäsenille? Mitkä asiat voisivat tukea halua olla mukana keskinäisessä vuorovaikutuksessa aktiivisena viestintätoimijana? Mitä aktiivinen osallisuus viestinnässä vaatii yksittäisiltä asiantuntijoilta? Mitä organisaatiolta edellytetään, että jokainen voisi tuntea olevansa aidosti mahdollistettu osallistumaan organisaation sisäiseen viestintään?

\section{Analyysi}

Haastattelut litteroitiin, jolloin analysoitavaksi kertyi 118 sivua (69 400 sanaa) kirjallista aineistoa. Aineisto analysoitiin teoriasidonnaista sisällönanalyysia noudattaen, jolloin aiempi tutkimustieto ja ymmärrys toimijuudesta toimi apuna analyysin etenemisessä, vaikka analyysi ja tavat jäsentää aineistoa pohjasivat ennen kaikkea kerättyyn aineistoon (ks. esim. Kovács \& Spens 2005; Mayring 2000; Tuomi \& Sarajärvi 2004). Teoriasidonnaisessa analyysissa teorianmuodostus nähdään yleensä mahdolliseksi silloin, kun havaintojen tekoon liittyy jokin johtolanka tai -ajatus (Alasuutari 2007; Tuomi \& Sarajärvi 2004, 97). Tämän artikkelin johtoajatus kumpuaa teoriaosuudessa esitellystä subjektikeskeisestä sosiokulttuurisesta lähestymistavasta, jossa tarkastellaan sekä toimijuuden yksilöllisiä että yhteisöllisiä tekijöitä (Eteläpelto ym. 2013; 2014; Vähäsantanen 2013). Toisin sanoen esimerkiksi tämä jako toimijuuden yksilöllisiin ja sosiokulttuurisiin tekijöihin ohjasi osaltaan niin tutkimuskysymyksen muodostamista kuin aineiston analyysia, kun taas esimerkiksi toimijuuden ja johtajuuden yhteyksiin alettiin kiinnittää huomiota vasta aineistoon tutustumisen ja analyysin edetessä. 
Tutkimusaineisto päätettiin analysoida teemoittelemalla, sillä se nähdään usein sopivana tapana poimia oleellista tietoa käytännöllisen tutkimusongelman ratkaisemiseksi (Eskola \& Suoranta 1996, 139). Käytännössä teemoittelu tarkoitti sitä, että analyysissa pyrittiin aineistossa toistuvien ja tutkimuskysymyksen kannalta oleellisten teemojen etsimiseen, muodostamiseen ja ryhmittelyyn sekä teemojen yksityiskohtaiseen tarkasteluun. Teoriapohjan lisäksi analyysin ja tulkintojen tukena hyödynnettiin havaintoja ja taustatietoja, joita kohdeorganisaatiosta saatiin ennen haastatteluja työyhteisön fyysisiin tiloihin ja sisäisiin ohjeisiin tutustumalla sekä seuraamalla niin koko työyhteisön kuin pienempien tiimien kokouksia. Havaintoja ja muistiinpanoja hyödynnettiin taustatietona haastateltavien vastausten ymmärtämisessä, mutta koska niitä ei kerätty systemaattisella aineistonkeruun tavalla, ei niitä kuitenkaan sisällytetty varsinaiseen tutkimusaineistoon.

Ennen teemoittelua aineisto luettiin useaan kertaan huolellisesti läpi ja samalla aineiston yhteyteen lisättiin pohdintoja ja huomioita myöhemmän teemoittelun tueksi. Varsinaisen analyysin ensimmäisessä vaiheessa haastatteluteemoihin eli 1) avoimuuteen, 2) tiedon jakamiseen ja vuorovaikutukseen sekä 3) asiantuntijan rooliin liittyvät haastatteluvastaukset jaoteltiin uusien pääteemojen alle. Tässä artikkelissa keskitytään näistä kahteen, jotka ovat viestintätoimijuutta tukevat/rajoittavat yksilölliset tekijät sekä viestintätoimijuutta tukevat/ rajoittavat sosiokulttuuriset tekijät. Analyysissa hyödynnettiin koko haastatteluaineistoa, sillä haastateltavat pystyivät puhumaan viestintätoimijuudesta periaatteessa missä vaiheessa haastattelua tahansa.

Analyysin toisessa vaiheessa ensimmäisessä vaiheessa muodostettuja pääteemoja pilkottiin vielä tarkempiin alateemoihin. Esimerkiksi vies- tintätoimijuutta tukevat/rajoittavat yksilölliset tekijät -pääteeman alle muodostettiin alateema taidot, joka jaettiin analyysin edetessä edelleen sitä tarkentaviin "toisen tason alateemoihin" viestintä- ja tietotekniset taidot, itsereflektointi ja muilta oppiminen sekä arviointi- ja harkintakyky. Analyysiyksikkö oli lyhimmillään yksittäisen lauseen mittainen mutta usein pidempi tekstijakso niin, että jokainen aineistokatkelma muodosti itsenäisen merkityskokonaisuuden. Analyysin toisen vaiheen jälkeen tutkimuksen ongelmanasettelun kannalta oleellista ja jäsenneltyä aineistoa oli yhteensä 28 sivua. Analyysi eteni teema kerrallaan siten, että kutakin teemaa tarkasteltiin yksityiskohtaisemmin kokoamalla samaa teemaa koskevat aineistoesimerkit yhteen ja lukemalla niitä rinnakkain.

Analyysin kolmannessa vaiheessa pyrittiin nostamaan analyysin abstraktiotasoa, suhteuttamaan tutkimustuloksia toisiinsa ja tarkastelemaan niitä suhteessa aiempaan tutkimustietoon (ks. esim. Frey, Botan \& Kreps 2000, 384-385). Samalla tulosten jäsennystä tarkennettiin tulosten auki kirjoittamista varten ja varmistettiin, että kaikki pää- ja alateemojen nimet olivat mahdollisimman kuvaavia ja tarkkoja. Aivan analyysin päätteeksi aineistosta valittiin vielä tulosten yhteyteen kuvaavat aineistoesimerkit.

\section{Tulokset}

Tulosluku jakautuu kahteen osaan. Ensin käsitellään viestintätoimijuutta tukevia yksilöllisiä tekijöitä asiantuntijatyössä. Tämän jälkeen esitellään asiantuntijoiden viestintätoimijuuden rakentumiseen vaikuttavia sosiokulttuurisia tekijöitä.

\section{Viestintätoimijuutta tukevat yksilölliset tekijät}

Tulosten mukaan tärkeimmät yksilötason tekijät asiantuntijoiden viestintätoimijuuden ra- 
kentumisessa koskevat 1) viestinnän merkityksen hahmottamista, 2) taitoja, 3) asennetta ja motivaatiota sekä 4) identiteettiä.

\section{1) Viestinnän merkityksen hahmottaminen}

Asiantuntijoiden tiedon ja ymmärryksen taso koskien viestintää nähtiin hyvin oleellisena heidän viestinnällisten tapojen muodostumisessa. Viestinnän merkityksen ymmärtäminen ja hahmottaminen osana omaa asiantuntijuutta koettiin myös kehitystä kaipaavaksi asiaksi, jotta viestintätoimijuus voisi vahvistua. Viestinnän merkityksen ymmärtäminen yhdistettiin siis vahvasti osaksi sitä pohjaa, jolle asiantuntijat voivat rakentaa omaa rooliaan asiantuntijana ja viestintätoimijana.

"Jokaisen vaan pitää ymmärtää se viestinnän tärkeys ja merkitys. Sen kautta kun sen ymmärtää, niin sitten sitä kantaa oman vastuun millä tavalla ja mitä viestittää." H5

Myös viestinnän hahmottaminen koko organisaation näkökulmasta nähtiin oleellisena osana viestintätoimijuutta. Työyhteisön sisäinen yhteistyö ja keskinäinen viestintä koettiin sitä helpommaksi, mitä parempi kokonaiskäsitys asiantuntijoilla oli työyhteisöstään ja sen jäsenten rooleista. Juuri tästä syystä haastateltavat kokivat tärkeäksi parantaa ymmärrystään työyhteisöstään, sen viestinnästä ja moninaisista toimijoista. Se, kuinka selväksi oma rooli ja vastuualueet osana suurempaa kokonaisuutta koettiin, näytti vaikuttavan työnteon sujuvuuteen ja viestintätoimijuuteen.

"Siinä täytyy tietysti talon toiminta tuntee. Ja just tuntee se, että mitä ne muut tekee, mitä tietoo ne muut tarvii ja sehän meillä on tällä hetkellä nyt hakusessa." H7

\section{2) Taidot}

Tärkeimmät viestintätoimijuuden rakentumiseen yhdistetyt taidot asiantuntijatyössä olivat haastateltavien mukaan a) viestintä- ja tietotekniset taidot, b) itsereflektointi ja muilta oppiminen sekä c) arviointi- ja harkintakyky.

a) Viestintä- ja tietotekniset taidot. Etenkin kyky käyttää organisaation käytössä olevia viestintäkanavia ja -välineitä koettiin viestintätoimijuuden kannalta välttämättömäksi. Viestintätaidoissa korostuivat lisäksi kyky luoda ja ylläpitää vuorovaikutussuhteita, jolloin tärkeinä nähtiin niin ikään hyvät vuorovaikutustaidot sekä kuuntelu- ja reagointitaidot. Ne koettiin ylipäätään oleellisiksi asiantuntijatyön sujuvuuden kannalta.

"Sulla pitää olla todella hyvät vuorovaikutustaidot, ohjaukselliset taidot ja tavallaan kestää monenlaista siinä ja pystyä luovimaan. Pitää olla verkostoa keskeisimpään tonne ns. kentälle ja koko ajan ymmärtää tavallaan työnantajaa." H6

b) Itsereflektointi ja muilta oppiminen. Haastateltavat näkivät yhdessä toimimisen ja oppimisen tärkeinä voimavaroina niin oman asiantuntijuutensa ja viestintätoimijuutensa kuin keskinäisen viestintänsä kehittämisessä. Asiantuntijat kokivat, että heidän on jatkuvasti arvioitava omaa toimintaansa suhteessa muihin ja sen mukaan myös kehitettävä toimintatapojaan. Tämä koettiin helpoiten toteutettavaksi sujuvan keskinäisen vuorovaikutuksen kautta. Haastattelujen valossa näytti siltä, että kyky oppia muilta ja arvioida omaa toimintaa yhdistyy myös asiantuntijoiden viestintätoimijuuden kehittymiseen, etenkin oman organisaation kollektiivisia käytänteitä mukailevaksi.

"Sun on pakko peilata koko aika mitä muut tekee, et teenkö mä samalla tavalla. Elikkä teenkö, kun meillä on lait ja ohjeet, mitä meidän pitää noudat- 
taa, mutta niissä jonkun verran on sitä tulkintaa ja sitten on sisäisiä käytäntöjä, että me käytettäis sitä kaikki samalla tavalla. Elikkä ne arvopohjat ohjaa kuitenkin meidän toimintaa ja sillon ne ohjaa meidän viestintääkin." $\mathrm{H} 2$

c) Arviointi- ja harkintakyky. Haastateltavat kokivat, että jokaisen asiantuntijan on kyettävä itse arvioimaan yhä tarkemmin, mikä heille on tärkeää ja mikä ei, mikä tieto on jakamisen arvoista ja miten sitä kannattaisi jakaa. Ilman tiedon suodattamista ja jatkuvaa puntarointia sen oleellisuudesta etenkin itselleen asiantuntijat eivät nähneet mahdollisena tehdä työtään ja olla viestintätoimijoita.

"Meidän työhön kuuluu myöskin sen informaation vastaanottaminen, suodattaminen ja käsitteleminen. Tulee semmonen silmä, että 'tuota tietoa mä tarvitsen ja tuon voin deletoida pois'. [- -.] Jos kaiken suodattais ja kävis ikään kuin kunniallisesti läpi, niin mä voisin lakata ottamasta asiakkaita kokonaan." H12

\section{3) Asenne ja motivaatio}

Asiantuntijoiden viestintätoimijuudessa henkilökohtainen asenne ja motivaatio nähtiin tärkeinä. Haastateltavien mukaan asiantuntijoiden ottama rooli ja aktiivisuus keskinäisessä vuorovaikutuksessa määrittyvät pääasiassa juuri niiden pohjalta. He kokivat, että mikäli puitteet ja tarjotut mahdollisuudet viestintätoimijuuteen ovat kunnossa, jää vastuu niiden hyödyntämisestä lopulta aina asiantuntijoille itselleen. Asenteeseen ja motivaatioon liitetyt seikat, jotka koettiin aktiivista viestintätoimijuutta rakentaviksi, olivat a) vastuun ottaminen ja kantaminen, b) yhteisöllinen ajattelutapa, c) ammatillinen innostus ja kunnianhimo sekä d) halu kehittyä.

a) Vastuun ottaminen ja kantaminen. Haastateltavat sijoittivat vastuun ottamisen ja kan- tamisen omista viestintätaidoista, aktiivisuudesta ja viestintätoimijuudesta osaksi jokaisen asiantuntijan työnkuvaa. Tämä korostui etenkin omaan substanssiosaamiseen ja erityisalaan liittyvistä asioista keskustelemisessa, tiedon luomisessa ja jakamisessa. Lisäksi oma vastuu liitettiin tiedonhakuun ja etsimiseen, sillä haastateltavat kokivat, että työssään heidän on lopulta huolehdittava aina itse tarvitsemansa tiedon löytämisestä.

"Jos perusta on selvä, että sä tiedät missä se tieto on, niin sithän se on vaan sun vastuulla et sä löydät sen." $H 8$

b) Yhteisöllinen ajattelutapa. Yhteisöllinen ajattelutapa nähtiin arvokkaana piirteenä asiantuntijatyössä, sillä sen myötä myös viestinnällisten toimien uskottiin olevan yhteiseen hyvään pyrkiviä ja koko työyhteisöä hyödyttäviä. Haastattelujen mukaan yhteisöllinen ajattelutapa voi tukea sitä, että yksilöt hahmottavat roolinsa osana suurempaa kokonaisuutta ja uskaltavat viestinnällään tuoda esiin niin omaa osaamistaan kuin tarpeitaan, mikä mahdollistaa sujuvan yhteistyön ja parhaimpien kollektiivisten ratkaisujen löytämisen.

"Et semmonen tietyllä lailla jatkuva refleksiivinen tai reflektiivinen työskentelytapa. Ja siihen semmonen vilpitön tutkiva ote. Että 'hei, mites tää nyt menikään?'. Tavallaan et kun eihän tämmöstä työtä voi kukaan omistaa. Ei juurikaan pitäs olla egon kans mitään tekemistä että 'tää on mun juttu', vaan tää on täydellinen palveluammatti." H6

c) Ammatillinen innostus ja kunnianhimo. Haastateltavat kokivat, että motivaatio ja kiinnostus ylipäätään omaan työhön ja asiantuntijuuteen ovat oleellisia vaikuttimia siihen, kuinka asiantuntijat toimivat viestinnällisesti omassa työyhteisössään. He kokivat, että ammatillinen innostus on yhteydessä myös siihen, 
miten asiantuntijat pyrkivät rakentamaan ja kehittämään viestintätoimijuuttaan.

"Totta kai jos se asia on semmonen kiinnostava ja sä haluut siihen vaikuttaa, niin totta kai sä tuot sen oman mielipitees esille. [- -.] Et paljon se on siitä omasta motivaatiosta ja kiinnostuksesta sitten, et miten haluaa vaikuttaa asioihin ja miten se koskee itseä se asia." H9

Tulosten mukaan vuorovaikutukseen motivoi työssä viihtyminen, vastavuoroisuus ja yhteisen hyvän saavuttaminen. Tietoa ja osaamista jaettiin toisten kanssa todennäköisemmin silloin, kun sen koettiin hyödyttävän myös muita ja helpottavan työntekoa yleisesti organisaation sisällä. Niin ikään arvostuksen ja luottamuksen kokeminen esimerkiksi palautteen tai vastuun saamisen muodossa koettiin motivoivaksi. Muiden auttamisen ja vastavuoroisuuden lisäksi keskinäisen viestinnän koettiin mahdollistavan oman asiantuntijuuden esiin tuomista ja tarjoamista muiden käyttöön ja siten myös vahvistavan sitä. Näin ollen myös ammatillinen kunnianhimo näytti aktivoivan viestinnällisiä toimintatapoja ja tukevan viestintätoimijuuden rakentumista.

"Ammatillinen kunnianhimo, et tietää et tää on jotenkin tärkeätä. Semmonen ikään kuin jakamisen ilo siitä. Ja sitten että voi tarjota sitä omaa osaamistaan. Et jokaisella on sitä omaa osaamistaan, vois tarjota sitä siihen prosessiin." H12

d) Halu kehittyä. Haastateltavien mukaan jokaisen asiantuntijan on mahdollista oppia uusia vuorovaikutustaitoja ja kehittyä viestintätoimijana, mikäli oma asenne ja motivaatio pohjaavat haluun oppia ja kehittyä. Lisäksi yhteisöllinen oppiminen ja kehittyminen koettiin tärkeinä ja mielekkäinä niin oman viestintätoimijuuden ja asiantuntijuuden kuin koko orga- nisaation asiantuntijayhteisön ja sen viestinnän kehittämisessä.

"Että kuitenkin aina tulee muutoksia ja näin. Niin niitten perässä ois jotenki pysyttävä. Niin sit se vaatis kyllä sitä motivoituneisuutta ja kaikilta sitä osallistumista yhteisen hyvän eteen. Et ei kai sitä oo koskaan liikaa sitä vuorovaikutusta." H9

\section{4) Identiteetti}

Tulosten mukaan vahva ja selkeä viestinnällinen identiteetti eli käsitys siitä, millainen viestijä asiantuntija on ja millaiseksi viestijäksi hän haluaa tulla, tukee viestintätoimijuuden rakentumista. Haastattelujen mukaan selkeä käsitys omasta ammatillisesta ja viestinnällisestä identiteetistä voi muun muassa auttaa asiantuntijoita hahmottamaan tarkemmin kokemiaan kehitystarpeita, suhdetta oman toiminnan nykytilan ja mahdollisen tavoitetilan välillä sekä niihin liittyviä tekijöitä ja parhaita ratkaisuja. Haastateltavat kokivat, että viestinnällisen identiteetin selventäminen ja vahvistaminen toimii oleellisena pohjana niin yksilön asiantuntijuuden ja viestintätoimijuuden kuin koko työyhteisön ja sen viestinnän kehittämisessä. Haastateltavat kokivat, että oman viestinnällisen identiteetin hahmottamista haastoi kuitenkin välillä se, että oma asiantuntijuus ja viestinnän rooli omassa työssä olivat monimuotoisempia kuin koulutus oli ollut.

"Tavallaan se tuottaa semmosta tarpeetonta ahdistusta ja asiantuntijuutensa ja toimijuuden horjumista. [- -.] Että en mä voi sanoo, että mä oisin oikeesti mikään [- -] asiantuntija just sen takia, et ei mulla nyt juurikaan oo hajua mitä tuolla tehdään." H6 


\section{Viestintätoimijuutta tukevat sosiokulttuuriset tekijät}

Tulosten mukaan viestintätoimijuuden rakentumista asiantuntijatyössä tukevia sosiokulttuurisia tekijöitä ovat 1) otolliset viestinnän puitteet, 2) mahdollistava johtaminen sekä 3) asiantuntijuuteen rohkaiseminen yksilöllisyyttä kunnioittaen.

\section{1) Otolliset viestinnän puitteet}

Asiantuntijat kokivat, että viestintävälineiden priorisoiminen, niiden käyttöön liittyvien käytänteiden yhtenäistäminen sekä sisäisen viestinnän merkityksen kirkastaminen voisivat luoda työympäristöön otollisemmat puitteet aktiiviselle viestinnälle ja viestintätoimijuuden rakentumiselle niin henkilökohtaisesti kuin kollektiivisesti. Ennen kaikkea viestinnällisten puitteiden toivottiin rakentuvan asiantuntijoiden tarpeita vastaavista välineistä ja tavoista. Oleelliseksi koettiin myös johdon viestinnän yhtenäisyys sekä tarvittavan ohjauksen saaminen viestintävälineiden käyttöön ja omien taitojen kehittämiseen. Otollisten viestinnän puitteiden uskottiin helpottavan tiedon ja etenkin sen määrän hallintaa. Haastateltavat kertoivat aktivoituvansa viestinnällisesti mielellään uudenlaisillakin tavoilla, kunhan välineet ja yhteiset pelisäännöt ovat selvät, jolloin myös viestintätoimijana oleminen koettiin helpommaksi ja mielekkäämmäksi.

"Voisko olla myös tiedotuskanavat, jotka kulkis vähän niinku talossa kulkee vesijohdot ja viemärijohdot ja sähköjohdot, on kylmä vesi ja lämmin vesi ja viemäri. Niin jokainen tietää mitä niissä on. Joku semmonen selkeys. Ja ne kattaa sen koko organisaation. Ne on käytettävissä, mut sä käytät aina ikään kuin sen tarpeen mukaan myöskin.” H12

\section{2) Mahdollistava johtaminen}

Asiantuntijat toivoivat ympärilleen työntekijöiden keskinäistä vuorovaikutusta tukevaa ilmapiiriä ja toimintakulttuuria. He toivoivat voivansa tuntea, että heillä on lupa viestiä oma-aloitteisesti ja avoimesti ja että johto suhtautuu tähän avoimuuteen sitä tukevasti. Vahvan hierarkkisen järjestyksen säilyttämisen sijaan asiantuntijat odottivat johtamistapojen korostavan jatkossa ennemmin moniammatillisen asiantuntijuuden toimivuutta yhtenä kokonaisuutena, jolloin toimintaa olisi toki ohjattava, mutta samalla tulisi tuottaa osin myös sitä vapauttavia tekniikoita.

Tarkemmin johtamisen toivottiin olevan vapaampaa viestintätoimijuutta mahdollistavaa, motivoivaa ja rohkaisevaa, asiantuntijoita valtuuttavaa ja vastuuttavaa ja siten myös luottamusta osoittavaa. Johdon toivottiin suhtautuvan asiantuntijoihin tasavertaisempina kumppaneina ja kunnioittavan heille annettua suurempaa viestinnällistä valtaa. Heidän toivottiin myös jakavan selvästi viestintävastuuta etenkin niille, jotka haluavat vaikuttaa ja tehdä töitä yhteisten asioiden eteen. Tärkeänä roolina nähtiin myös aloitteellisena suunnannäyttäjänä toimiminen, jolloin johdon viestinnän toivottiin olevan esimerkillistä, kuuntelevaa ja yhdenmukaista.

Avoimeen tiedon jakamiseen johtajien toivottiin panostavan muun muassa kuuntelemalla sekä tarjoamalla asiantuntijoille aitoja mahdollisuuksia osallistua viestintään ja päätöksentekoon. Haastateltavat arvostivat ennen kaikkea vuorovaikutusta, joka on luonteeltaan sallivaa ja erilaisia näkemyksiä mahdollistavaa, eikä niinkään täydelliseen yhteisymmärrykseen pyrkivää. Ylipäätään johdon tulisi tulosten mukaan mahdollistaa sujuva ja esteetön vuorovaikutus ja tiedon jakaminen sekä tehdä tiedon hyödyntämisestä ja soveltamisesta mahdollisimman helppoa. 
Liian tiukan hallinnan uskottiin rajoittavan työntekijöiden viestintätoimijuutta. Koettuina esteinä nähtiin työpaikan valtasuhteet, niiden vaikutukset toiminta- ja puhetapoihin sekä niiden kautta rakentuvat turhan hierarkkisiksi koetut ammatilliset roolit ja asemat. Vaativan asiantuntijatyön ei uskottu onnistuvan tehokkaimmin käskytyksen tai ulkoisen kontrollin kautta, vaan ennemmin valtauttamalla työntekijöitä oman työnsä vaikuttajiksi ja toimijoiksi. Haastateltavat toivoivat johdon ennemmin mahdollistavan heidän autonomiaansa ja osoittavan luottamusta heidän osaamiseensa kuin rajoittavan ja ohjaavan liikaa heidän työntekoaan. Samoin ammatillisiin asemiin liittyviä rooleja ja valtaeroja toivottiin purettavan, jotta toisten lähestyminen ja keskinäinen vuorovaikutus koettaisiin sujuvammaksi.

"[- -] johdolla on juuri se rooli. Että se edistää sitä organisaation toimivuutta ja sujuvuutta sen sijaan, että tarttuu asiantuntijoiden paimentamiseen. Että enemmän mahollistaa ja luo sitä autonomiaa ihmisille, mikä tuottaa semmosta ehkä aidompaa dialogisuutta ja sitä avointa viestintää." H6

3) Asiantuntijuuteen rohkaiseminen yksilöllisyyttä kunnioittaen

Haastateltavien mukaan on oleellista, että organisaatio huolehtii asiantuntijoiden tarpeeksi selvistä rooleista ja työnkuvista. Tulosten mukaan niiden selkeys vaikuttaa myös viestintätoimijuuteen, ja haastateltavat toivoivatkin selkeämpiä odotuksia ja roolinjakoa myös viestintään. Tämän lisäksi haastateltavat kokivat, että viestintätoimijuuden tukemisen kannalta on tärkeää, että asiantuntijoita rohkaistaan ottamaan asiantuntijan ja aktiivisen viestijän rooli työyhteisössään.

"Se lähtis siitä, et me saatas tätä asiantuntijuutta edelleen vahvistettua, sitä et mitä on olla oikeesti asiantuntija. Että ihmiset oikeesti uskaltas ottaa sen asiantuntijan roolin." $\mathrm{H7}$

Tuen ja rohkaisun lisäksi haastatteluissa painottui yksilöllisten erojen huomioiminen ja niiden kunnioittaminen. Haastateltavat kokivat, ettei kaikkia asiantuntijoita voida tai pidä istuttaa samaan muottiin viestinnällistenkään ominaisuuksien tai tapojen suhteen, vaan sen sijaan on painotettava joustavaa ja sallivaa rohkaisua sekä matalan kynnyksen mahdollisuuksien luomista ja tarjoamista yhteisesti koko työyhteisölle. Erityisesti organisaation sisäisten vuorovaikutustapojen ohjaaminen yhteisöllistä oppimista edistäväksi ilmeni tehokkaaksi miellettynä ja pidettynä keinona viestintätoimijuuden tukemisessa. Tukemalla asiantuntijoidensa viestintätoimijuutta organisaatio voi tulosten valossa myös laajemmin tukea yksilöiden kehittymistä ja työstä suoriutumista sekä edistää heidän mahdollisuuksiaan vastata paremmin työelämän uusiin vaatimuksiin.

"Ja asiantuntijuus kasvaa viestinnän kautta. Jaetaan tietoo toisillemme, opitaan toisiltamme. [- -.] Et myöskään meidän toiminta ei sillon kehity, jos tiedon jakamista jotenkin säännellään ja yhdessä pohtimista." $\mathrm{H7}$

\section{Pohdinta}

Tulosten mukaan asiantuntijoiden viestintätoimijuutta tukevat yksilötasolla viestinnän merkityksen hahmottaminen, taidot, asenne ja motivaatio sekä identiteetti. Sosiokulttuurisista tekijöistä tärkeiksi koettiin sen sijaan otolliset viestinnän puitteet, mahdollistava johtaminen sekä asiantuntijuuteen rohkaiseminen yksilöllisyyttä kunnioittaen. Keskeisimmät tutkimustulokset ja viestintätoimijuuden määritelmä on koottu kuvioon 2. 


\begin{tabular}{|c|c|c|}
\hline $\begin{array}{l}\text { VIESTINTÄTOIMIJUUTTA } \\
\text { TUKEVAT } \\
\text { SOSIOKULTTUURISET } \\
\text { TEKIJÄT } \\
\text { Otolliset viestinnän puitteet } \\
\text { Mahdollistava johtaminen } \\
\text { Asiantuntijuuteen } \\
\text { rohkaiseminen } \\
\text { yksilöllisyyttä kunnioittaen }\end{array}$ & $\begin{array}{l}\text { Prosessi, jossa asiantuntijayksilöt, } \\
\text { ryhmät tai kokonaiset työyhtei- } \\
\text { söt ilmaisevat ja työstävät työnsä } \\
\text { viestinnällisiin aspekteihin liittyviä } \\
\text { valintoja ja pyrkimyksiä, ottavat } \\
\text { kantaa, osallistuvat ja vaikuttavat } \\
\text { viestintään työssään sekä neuvot- } \\
\text { televat ammatillisista identiteeteis- } \\
\text { tään viestinnän osalta. }\end{array}$ & $\begin{array}{c}\text { VIESTINTÄTOIMIJUUTTA } \\
\text { TUKEVAT } \\
\text { YKSILÖLLISET } \\
\text { TEKIJÄT } \\
\text { Viestinnän merkityksen } \\
\text { hahmottaminen } \\
\text { Taidot } \\
\text { Asenne ja motivaatio } \\
\text { Identiteetti }\end{array}$ \\
\hline
\end{tabular}

\section{KUVIO 2 Viestintätoimijuutta tukevat yksilölliset ja sosiokulttuuriset tekijät}

Tulokset tukevat aiempia näkemyksiä esimerkiksi osaamisen, identiteetin, materiaalisten ehtojen ja valtasuhteiden roolista toimijuuden mahdollistumisessa (Eteläpelto ym. 2014, 211). Ne tuovat kuitenkin toimijuuden tarkasteluun myös uusia näkökulmia nostamalla eksplisiittisemmin esiin esimerkiksi asenteiden ja motivaation sekä mahdollistavan johtamisen merkityksen viestintätoimijuuden rakentumisessa.

Tulosten mukaan viestintätoimijuus rakentuu työyhteisön vuorovaikutussuhteissa. Yksilötason tekijät, kuten asiantuntijoiden vuorovaikutusosaaminen, sekä sosiokulttuuriset tekijät, kuten työyhteisön viestintäkäytänteet ja johtaminen, asettavat asiantuntijoiden viestintätoimijuudelle reunaehtoja ja voivat joko edistää tai ehkäistä viestintätoimijuutta. Asiantuntijat kuitenkin myös uusintavat käytäntöjä ja muuntavat vuorovaikutussuhteita sekä työyhteisönsä viestintää viestintätoimijuutensa kautta. Sama periaate on tuotu esiin aiemminkin: esimerkiksi Giddensin (1984) strukturaatioteorian mukaan rakenteet rajoittavat ja mahdollistavat toimijuutta mutta myös muuttuvat ajan kuluessa, sillä yksilöt uudistavat ja muokkaavat toimijoina kyseisiä rakenteita. Toimijuudella voidaankin myös vaikuttaa toimijuuden edellytyksiin: esimerkiksi Eteläpellon ym. $(2014,212)$ mukaan osaaminen on toimijuuden edellytys, mutta toimijuus myös lisää mahdollisuutta kehittää omaa osaamista.

Viestintätoimijuutta tukevien ja rajoittavien yksilöllisten ja sosiokulttuuristen tekijöiden väliltä löytyy mielenkiintoisia yhtymäkohtia mutta myös ristiriitoja. Haastateltavat muun muassa toivoivat voivansa työskennellä riittävän tasa-arvoisessa, avoimessa ja läpinäkyvässä työyhteisössä ja näkivät liian jäykät hierarkkiset rakenteet, ammatilliset positiot ja valtasuhteet viestintätoimijuuden esteinä. Samaan aikaan he kuitenkin toivoivat riittävän selvien pelisääntöjen ja rajojen luomista, yhtenäisten viestintäkäytänteiden varmistamista sekä roolien selkiyttämistä. Asiantuntijoiden viestintätoimijuuden tukemisessa näyttäisikin olevan haasteena antaa asiantuntijoille samaan aikaan riittävästi vapautta, valtaa ja vastuuta ja luoda samaan aikaan toimijuuden toteuttamiselle tarpeeksi yhtenäiset ja selkeät raamit. Lisähaasteena on asiantuntijoiden tasapuolinen tukeminen, mutta samalla heidän yksilöllisten erojen, tarpeiden ja toiveiden huomioiminen ja 
kunnioittaminen myös sen suhteen, miten aktiivisia viestintätoimijoita he ylipäänsä haluavat olla.

Tulokset tarjoavat hyödyllistä tietoa asiantuntijaorganisaatioille ja asiantuntijoille, jotka tahtovat panostaa aktiivisempien, vuorovaikutteisempien ja osallistavampien viestintätapojen hyödyntämiseen ja jalkauttamiseen. Viestintätoimijuuden valossa on mahdollista tarkastella esimerkiksi yksilön vuorovaikutusosaamisen sijaan laajemminkin hänen toimintaansa, rooliaan ja osallisuuttaan työyhteisönsä tai organisaationsa viestinnässä. Käsite suuntaa huomion yksilöllisten ja sosiokulttuuristen resurssien ja reunaehtojen mahdollistamaan tai estämään prosessiin. Näin ollen käsitteen avulla yksilöiden ja työyhteisöjen viestinnän sekä siihen sisältyvien käytäntöjen ja tapojen tarkempi hahmottaminen voi olla helpompaa. Tällöin myös erityistä kehitystä kaipaavien työyhteisöviestinnän osa-alueiden kartoittaminen voi olla tarkempaa.

Viestinnän ammattilaiset ja kouluttajat, ja etenkin sisäisestä viestinnästä vastaavat henkilöt, voivat hyötyä viestintätoimijuuden käsitteen ja sitä tukevien tekijöiden tiedostamisesta, esiin nostamisesta ja soveltamisesta organisaatiossaan, kun he pyrkivät kehittämään omaa ja koko työyhteisönsä viestintää. Käsitteen avaaminen voi esimerkiksi auttaa heitä kiinnittämään huomiota myös työntekijöiden viestinnällisen identiteetin rakentumiseen sekä asenteisiin ja motivaatioon; keskittyyhän vuorovaikutusosaamisenkin tarkastelu usein pelkästään taitoihin, ellei käsitettä avata ja sen sisältöä tunneta tarkemmin (Laajalahti 2014, 330). Kaikkinensa viestintätoimijuuden käsite voi auttaa tarkastelemaan työyhteisöjen toimintaa sekä työhön sisältyviä vuorovaikutussuhteita ja -tilanteita uudenlaisista näkökulmista.
Asiantuntijaorganisaatiot voivat kehittää toimintaansa yksilöiden ja koko työyhteisön viestintätoimijuutta tukevaksi monin keinoin. Ensinnäkin johdon tulisi mahdollistaa sujuva ja esteetön vuorovaikutus ja tiedon vaihdanta sekä tehdä tiedon hyödyntämisestä ja soveltamisesta mahdollisimman helppoa. Organisaation on myös kannattavaa nostaa esiin niitä tekijöitä, joihin panostaminen voi auttaa asiantuntijoita kehittämään niin omaa kuin koko työyhteisön yhteistä viestintätoimijuutta. Viestintätoimijuuteen motivoimiseksi asiantuntijoille voidaan korostaa, että panostamalla viestintätoimijuuteen heidän on mahdollista helpottaa työntekoaan ja että aktiivisina viestintätoimijoina heillä on paremmat mahdollisuudet oppia muilta ja muiden kanssa, tuoda esille asiantuntemustaan ja hyödyntää osaamistaan sekä ottaa kantaa ja vaikuttaa siihen, millaisessa työyhteisössä he työskentelevät.

Viestintätoimijuuden ymmärtäminen ja käsitteen jatkokehittely edellyttää lisätutkimusta. Ensinnäkin tarvitaan tutkimusta, miten viestintätoimijuus ilmenee työyhteisöissä ja millainen viestintätoimijuus on eri tahojen kannalta ylipäänsä toivottavaa. Myös viestintätoimijuuden tärkeys ja seuraukset kaipaavat lisäselvitystä. Ymmärrys viestintätoimijuudesta voisi syventyä esimerkiksi siten, että sen käsitteellistämisessä huomioitaisiin jatkossa paremmin toimijuuden ja refleksiivisyyden suhde (ks. lisäksi Archer 2010) tai vaikkapa organisaatioon sitoutumisen/sitouttamisen (employee engagement) tai organisaatiokulttuurin ja viestintätoimijuuden yhteydet. Viestintätoimijuuden syvällisempi teoretisointi ja operationaalistaminen lisäisi myös mahdollisuuksia kehittää sitä edistäviä yksilöllisiä resursseja ja sosiokulttuurisia reunaehtoja ja tukisi näin viestintätoimijuuden rakentumista ja rakentamista. 
Tässä artikkelissa keskityttiin sekä asiantuntijoiden viestintätoimijuuden yksilöllisiin että sosiokulttuurisiin resursseihin, mutta viestintätoimijuutta lähestyttiin lähinnä asiantuntijayksilöiden näkökulmasta. Jatkossa onkin tärkeää tarkastella myös esimerkiksi ryhmien, tiimien ja kokonaisten työyhteisöjen yhteistä viestintätoimijuutta. Silvennoisen $(2014,163)$ mukaan koulutus näyttäytyy usein resurssina, joka vahvistaa yksilöiden toimijuutta ja varustaa heitä keskinäiseen kilpailuun työstä ja asemista. Tämän vuoksi nimenomaan kollektiivisen, koko työyhteisön yhteisen viestintätoimijuuden tutkiminen ja tukeminen on jatkossa erityisen tärkeää. Artikkelissa keskityttiin asiantuntijoina toimivien työntekijöiden näkemyksiin, joten jatkossa tarvittaisiin myös tutkimuksia, joissa selvitettäisiin johdon edustajien kokemuksia ja käsityksiä viestintätoimijuudesta. Hedelmällistä olisi myös tarkastella, mitkä yksilölliset ja sosiokulttuuriset tekijät ovat merkittävimpiä viestintätoimijuuden kannalta, mihin ei vielä tämän tutkimuksen puitteissa voida ottaa kantaa.

Artikkelissa tarkasteltiin viestintätoimijuutta asiantuntijayksilöiden tulkintojen ja merkityksenantojen kautta. Jatkossa viestintätoimijuuden ilmentymiä voisi kuitenkin tutkia myös esimerkiksi kielenkäytössä, kulttuurisissa käytänteissä, sosiaalisissa normeissa ja valtasuhteissa näkyväksi tulevana ilmiönä (ks. lisäksi Eteläpelto ym. 2014). Tarvitaan myös pitkittäistutkimusta, joka huomioi viestintätoimijuuden kehittymisen ja ajallisen muuttuvuuden. Eräs jatkotutkimushaaste kohdistuukin viestintätoimijuuden käsitteen soveltamiseen työn ulkopuolisiin konteksteihin ja tarkasteluun koko ihmisen elämänkulun ja kehittymisen näkökulmasta.

${ }^{1}$ Artikkeli perustuu Birgitta Kemppaisen (2016) yhteisöviestinnän maisterintutkielmaan, jonka ohjaajana toimi Anne Laajalahti Jyväskylän yliopiston viestintätieteiden laitokselta.

\section{Kirjallisuus}

Alasoini, T., Järvensivu, A. \& Mäkitalo, J. 2012. Suomen työelämä vuonna 2030: miten ja miksi se on toisennäköinen kuin tällä hetkellä. TEM raportteja 14/2012. Helsinki: Työ- ja elinkeinoministeriö. <https://www.tem.fi/files/33157/TEMrap_14_2012. pdf>. Viitattu 11.4.2016.

Alasuutari, P. 2007. Laadullinen tutkimus. 6. painos. Tampere: Vastapaino.

Archer, M. S. 2010. Conversations about reflexivity. London: Routledge.

Barge, J. K. 2014. Communication competence and systemic practice. Teoksessa S. W. Littlejohn \& S. McNamee (toim.) The coordinated management of meaning: a festschrift in honor of W. Barnett Pearce. Madison: Fairleigh Dickinson University Press, 137160.

Campbell, K. K. 2005. Agency: promiscuous and protean. Communication and Critical/Cultural Studies 2 (1), 1-19.

Edwards, A. 2005. Relational agency: learning to be a resourceful practitioner. International Journal of Educational Research 43 (3), 168-182.

Edwards, A. 2010. Being an expert professional practitioner: the relational turn in expertise. Dordrecht: Springer.

Eskola, J. \& Suoranta, J. 1996. Johdatus laadulliseen tutkimukseen. Tampere: Vastapaino.

Eteläpelto, A., Vähäsantanen, K., Hökkä, P. \& Paloniemi, S. 2013. What is agency? Conceptualizing professional agency at work. Educational Research Review 10, 45-65.

Eteläpelto, A., Vähäsantanen, K., Hökkä, P. \& Paloniemi, S. 2014. Miten käsitteellistää ammatillista toimijuutta työssä? Aikuiskasvatus 34 (3), 202-214.

Evans, K. 2007. Concepts of bounded agency in education, work, and the personal lives of young adults. International Journal of Psychology 42 (2), 85-93.

Frey, L. R., Botan, C. H. \& Kreps, G. L. 2000. Investigating communication: an introduction to research methods. 2. painos. Needham Heights: Allyn and Bacon.

Giddens, A. 1984. The constitution of society: outline of the theory of structuration. Cambridge: Polity.

Greene, J. O. \& Burleson, B. R. (toim.) 2003. Handbook of communication and social interaction skills. Mahwah: Erlbaum.

Haapasaari, A., Engeström, Y. \& Kerosuo, H. 2016. The emergence of learners' transformative agency 
in a change laboratory intervention. Journal of Education and Work 29 (2), 232-262.

Hirsjärvi, S. \& Hurme, H. 2001. Tutkimushaastattelu: teemahaastattelun teoria ja käytäntö. Helsinki: Gaudeamus.

Hitlin, S. \& Elder, G. H. Jr. 2007. Time, self, and the curiously abstract concept of agency. Sociological Theory 25 (2), 170-191.

Huotari, M.-L., Hurme, P. \& Valkonen, T. 2005. Viestinnästä tietoon: tiedon luominen työyhteisössä. Helsinki: WSOY.

Juholin, E. 2013. Arvioi ja paranna! Viestinnän mittaamisen opas. Helsinki: Talentum.

Julkunen, R. 2011. Työ - talouden ja minän välissä. Teoksessa A. Eteläpelto, K. Collin \& J. Saarinen (toim.) Työ, identiteetti ja oppiminen. Helsinki: WSOY, 18-48.

Jyrkämä, J. 2008. Toimijuus, ikääntyminen ja arkielämä - hahmottelua teoreettis-metodologiseksi viitekehykseksi. Gerontologia 22 (4), 190-203.

Kallio, P. 2014. Esimiehen muuttuvat identiteetit: narratiivinen tutkimus keskijohdon identiteeteistä ja samastumisesta organisaatiomurroksessa. ItäSuomen yliopisto. Dissertations of Education, Humanities, and Theology 54.

Kemppainen, B. 2016. Kohti vuorovaikutteista ja osallistavaa sisäistä viestintää: viestintätoimijuuden edellytykset. Jyväskylän yliopisto, viestintätieteiden laitos. Yhteisöviestinnän maisterintutkielma.

Kerosuo, H. 2014. Kollektiivinen muutostoimijuus - esimerkkinä solmutyöskentely rakennusalan kehittämishankkeessa. Aikuiskasvatus 34 (3), 178191.

Kovács, G. \& Spens, K. M. 2005. Abductive reasoning in logistics research. International Journal of Physical Distribution \& Logistics Management 35 (2), 132-144.

Laajalahti, A. 2014. Vuorovaikutusosaaminen ja sen kehittyminen tutkijoiden työssä. Jyväskylän yliopisto. Jyväskylä Studies in Humanities 225.

Laulainen, S. 2010. "Jos mittää et anna niin mittää et saa": strateginen toimijuusja organisaatiokansalaisuus vanhustyössä. Itä-Suomen yliopisto. Dissertations in Social Sciences and Business Studies 9.

Lehtinen, A.-R. 2000. Lasten kesken: lapset toimijoina päiväkodissa. Väitöskirja. Jyväskylän yliopisto. SoPhi 55.

Li, C. 2010. Open leadership: how social technology can transform the way you lead. Hoboken: JosseyBass.
Mazzei, A. 2010. Promoting active communication behaviours through internal communication. Corporate Communications: An International Journal 15 (3), 221-234.

Mayring, P. 2000. Qualitative content analysis. Forum: Qualitative Social Research 1 (2), Art. 20.

Men, L. 2014. Strategic internal communication: transformational leadership, communication channels, and employee satisfaction. Management Communication Quarterly 28 (2), 264-284.

Mezirov, J. 1981. A critical theory of adult learning and education. Adult Education 32 (1), 3-24.

Pyöriä, P. 2006. Understanding work in the age of information: Finland in focus. Tampereen yliopisto. Acta Universitatis Tamperensis 1143.

Settersten, R. A. Jr. \& Gannon, L. 2005. Structure, agency, and the space between: on the challenges and contradictions of a blended view of the life course. Advances in Life Course Research 10, 35-55.

Silvennoinen, H. 2014. Koulutus toimijuuden vahvistajana. Aikuiskasvatus 34 (3), 162-163.

Spitzberg, B. H. \& Cupach, W. R. 2011. Interpersonal skills. Teoksessa M. L. Knapp \& J. A. Daly (toim.) The Sage handbook of interpersonal communication. 4. painos. Thousand Oaks: Sage, 481-526.

Tulevaisuusselonteko 2030. Hallituksen selonteko. $<$ http://www.2030.fi >. Viitattu 11.4.2016.

Tuomi, J. \& Sarajärvi, A. 2004. Laadullinen tutkimus ja sisällönanalyysi. 3. painos. Helsinki: Tammi.

Vanhalakka-Ruoho, M. 2014. Toimijuus elämänkulussa - ohjaustyön perusta? Aikuiskasvatus 34 (3), 192-201.

Virkola, E. 2014. Toimijuutta, refleksiivisyyttä ja neuvotteluja - muistisairaus yksinasuvan naisen arjessa. Jyväskylän yliopisto. Jyväskylä Studies in Education, Psychology and Social Research 491.

Vos, M. \& Schoemaker, H. 2011. Integrated communication: concern, internal and marketing communication. 4. painos. Portland: Eleven International Publishing.

Vähäsantanen, K. 2013. Vocational teachers' professional agency in the stream of change. Jyväskylän yliopisto. Jyväskylä Studies in Education, Psychology and Social Research 460.

Vähäsantanen, K., Paloniemi, S., Hökkä, P. \& Eteläpelto, A. 2014. Kohti ammatillisen toimijuuden monikytkentäistä vahvistamisohjelmaa. Teoksessa P. Hökkä, S. Paloniemi, K. Vähäsantanen, S. Herranen, M. Manninen \& A. Eteläpelto (toim.) Ammatillisen toimijuuden ja työssä oppimisen vahvistaminen luovia voimavaroja työhön! Jyväskylä: University Printing House, 217-226. 